\title{
Inhibitory effects of plant extracts on growth, development and $\alpha$-amylase activity in the red flour beetle Tribolium castaneum (Coleoptera: Tenebrionidae)
}

\author{
NUJiRA TATUN ${ }^{1}$, BoONGUEA VAJARASATHIRA² ${ }^{2}$ JATUPORn TUNGJITWITAYAKUL $^{1}$ and Sho SAKURAI ${ }^{3}$
}

\author{
${ }^{1}$ School of Science, University of Phayao, Phayao 56000, Thailand; e-mail: nujira.ta@up.ac.th \\ ${ }^{2}$ Department of Zoology, Faculty of Science, Kasetsart University, Bangkok 10900, Thailand \\ ${ }^{3}$ Division of Life Sciences, Graduate School of Natural Science and Technology, Kanazawa University, Kanazawa 920-1192, Japan
}

Key words. Coleoptera, Tenebrionidae, $\alpha$-amylase, amylase inhibitor, Carica papaya, Ricinus communis, Tribolium castaneum

\begin{abstract}
The bioinsecticidal effects of methanolic extracts of the leaves of castor bean, Ricinus communis, and papaya, Carica papaya, on the red flour beetle, Tribolium castaneum, were studied. More specifically, larval weight, larval mortality, percentage pupation, percentage adult emergence and F1 progeny production were recorded. We also studied the effects of the extracts on $\alpha$-amylase activity and amylase gene expression in $T$. castaneum. The extracts of $R$. communis and C. papaya, which were administered in a diet, increased larval mortality and extended the durations of the larval and pupal periods. Feeding them an extract-treated diet also reduced the percentages of larvae that pupated and of adults that emerged and the number of F1 progeny. $\alpha$-Amylase activity was inhibited and glucose content reduced in the larvae and adults of these insects. This inhibition of $\alpha$-amylase activity by the $R$. communis and $C$. papaya extracts was concentration dependent in vitro. In addition, amylase gene expression was reduced in insects fed a diet containing C. papaya, but not $R$. communis extract. These results indicate that the bioinsecticidal effects of the leaf extracts are mediated by inhibiting the gene expression and activity of enzymes involved in sugar metabolism.
\end{abstract}

\section{INTRODUCTION}

The red flour beetle, Tribolium castaneum, is a widespread pest, which feeds on a variety of stored dry products. The application of various synthetic insecticides and fumigants to stored grain has led to a number of adverse effects, including water and soil contamination, the development of insecticide resistance, toxicity to non-target organisms and effects on human health (Zettler, 1991). Therefore, there is an urgent need for safe, environmentally friendly alternatives, which has led to an increased use of natural products for the control of pests of stored products. Substantial efforts have focused on plant-derived materials for use as bioinsecticides, both because the development of pest resistance to plant extracts has not been reported and because the major components of plant extracts may be more rapidly degraded than synthetic materials (Koul \& Dhawiwal, 2001).

Living on a starch-rich diet, many insects depend on the enzymatic activity of amylase, or more precisely, $\alpha$-amylase, for survival. $\alpha$-Amylase ( $\alpha$-1,4-glucan-4-glucanohydrolase; EC3.2.1.1) is a hydrolytic enzyme found in microorganisms, plants and animals. This enzyme catalyzes the endohydrolysis of long $\alpha$-D-(1,4)-glucan chains, such as starch and related carbohydrates, allowing organisms to use starch as an energy source (Baker, 1991; Strobl et al., 1998). The starch is converted to maltose, which is then hydrolyzed to glucose by an $\alpha$-glucosidase, a particularly important hydrolytic enzyme for digestion in grain beetles (Terra \& Ferreira, 2005).

Among plant defence compounds, enzyme inhibitors are important because of their role in plant defence. Sev- eral kinds of $\alpha$-amylase inhibitors from seeds and vegetative organs of plants that are potential regulators of the numbers of insect pests, have been characterized. To date, $\alpha$-amylase inhibitors are classified into six different classes: lectin-like, knottin-like, cereal-type, kunitz-like, $\gamma$-purothionin-like and thaumatin-like (Franco et al., 2002) and are regarded as attractive candidates for controlling insects that are highly dependent on starch as an energy source. Wheat $\alpha$-amylase inhibitor causes a marked decrease in larval growth and increase in mortality in insects (Franco et al., 2005). Treatment with WRP24 $\alpha$-amylase inhibitor extracted from wheat inhibits the growth of larvae and induces weight loss in adult $T$. castaneum (Feng et al., 1996). $\alpha$-Amylase inhibitors from seeds of castor bean, Ricinus communis, and papaya, Carica papaya inhibit amylase activity and are used as insecticides against many species of coleopteran insect pests (Farias et al., 2007; Do Nascimento et al., 2011).

In this study we determined the effects the methanol extracts of papaya and castor bean leaves on the development of larvae, pupae and adults of T. castaneum. In addition, we determined the effects of the extracts on $\alpha$-amylase at the biochemical and gene expression levels.

\section{MATERIALS AND METHODS}

\section{Insect cultures}

T. castaneum was obtained from the Postharvest and Processing Product Research and Development Office, Department of Agriculture, Thailand. The insect cultures were maintained on a basic diet consisting of wheat flour containing $5 \%$ yeast kept at 30 $\pm 1{ }^{\circ} \mathrm{C}$ and a $70 \pm 5 \%$ relative humidity. In the present study, we used 22-day-old larvae and one-week-old adults unless specified 
otherwise. The feeding in the last instar/22 day-old larvae and prepupal period typically lasted for 5-6 days and 1-2 days, respectively. In our stock culture, the last larval instar was for most larvae the sixth (Minakuchi et al., 2009). The insects were starved for $24 \mathrm{~h}$ prior to use in bioassay experiments.

\section{Preparation of the plant and extracts}

Papaya and castor bean leaves were collected during June and July 2010 from Phayao Province, Thailand. The fresh leaves were rinsed with distilled water, dried in the shade and crushed to generate a fine powder. The plant powder $(20 \mathrm{~g})$ plus $160 \mathrm{~mL}$ of methanol was subjected to ultrasound for for $30 \mathrm{~min}$, maintained at $4^{\circ} \mathrm{C}$ for $48 \mathrm{~h}$ and then filtered through Whatman No. 1 filter paper (GE Healthcare Biosciences, Pittsburg, PA, USA). The filtrate on the filter paper was suspended again in $160 \mathrm{~mL}$ of methanol, and the same procedure repeated to obtain the second methanolic extract. The two methanolic extracts were then combined and evaporated to dryness and stored at $-20^{\circ} \mathrm{C}$.

\section{Bioassays}

Extract $(1 \mathrm{~g}$ ) was suspended in $1 \mathrm{~mL}$ of methanol and $0.5 \mathrm{~mL}$ of the suspension was mixed with $5 \mathrm{~g}$ of the basic diet (treated diet). A control diet was prepared by adding only $0.5 \mathrm{~mL}$ methanol to $5 \mathrm{~g}$ of the basic diet. The methanol was then allowed to evaporate at $37^{\circ} \mathrm{C}$ for $48 \mathrm{~h}$. Thirty newly moulted 22 day-old larvae were selected from the stock culture and placed in a plastic container, $4.5 \mathrm{~cm}$ in diameter and $6.5 \mathrm{~cm}$ deep, containing the treated or control diet. The body weights and mortality of the larvae were recorded each day and the days to pupal ecdysis were also recorded. To measure the pupal period, newly pupated insect were selected each day, kept individually and their day of emergence recorded. The percentage adult emergence was calculated based on the insects that successfully pupated. To assess the effect of the extracts on $\mathrm{F} 1$ progeny production, 30 adults were transferred to a plastic container that contained either the untreated (control) or treated diet. After $48 \mathrm{~h}$ these insects were transferred to a second container, which contained untreated diet. These plastic containers were kept under the same experimental conditions for 5 weeks during which time the number of $\mathrm{F} 1$ adults that emerged was counted. There were five replicates of this experiment.

For in vivo experiments, treated diets were prepared in the same way as described above and then the extract-treated diets were fed to the larvae or adults to determine their effects on level of $\alpha$-amylase activity, gene expression and glucose concentration in T. castaneum. The insects were reared on treated diet for 4 days and samples were collected every day for measuring $\alpha$-amylase activity. In order to determine the effects of plant extracts on the level of expression of the $\alpha$-amylase gene and changes in glucose concentration, samples of larvae and adults were collected two days post-treatment.

\section{Determination of $\alpha$-amylase activity}

Five insects were homogenized in $500 \mu \mathrm{L}$ of $20 \mathrm{mM}$ sodium acetate buffer, $\mathrm{pH} 5.5$, containing $10 \mathrm{mM} \mathrm{NaCl}$ and $20 \mathrm{mM}$ $\mathrm{CaCl}_{2}$. The homogenates were filtered through cheesecloth and centrifuged at $10,000 \times \mathrm{g}$ for $15 \mathrm{~min}$ at $4^{\circ} \mathrm{C}$. The supernatant was kept at $-20^{\circ} \mathrm{C}$ until used as an enzyme source. The amount of protein was determined prior to the $\alpha$-amylase assay using a protein dye-binding method (Bio-Rad, Hercules, CA, USA) with bovine serum albumin as the standard. The amount of protein in the insect extract was $18.2 \mu \mathrm{g} / \mu \mathrm{L}$. The $\alpha$-amylase activity was determined using a modified version of the procedures reported by Rekha et al. (2004). The activity was determined by incubating $15 \mu \mathrm{L}$ of the insect extract with $100 \mu \mathrm{l}$ of starch solution $(0.2 \%$ starch (Sigma, St. Louis, MO, USA) in $20 \mu \mathrm{M}$ sodium phosphate buffer, $\mathrm{pH} 6.0$ ) at $37^{\circ} \mathrm{C}$ for $10 \mathrm{~min}$. The reaction was stopped by the addition of $20 \mu \mathrm{L}$ of $1 \mathrm{M} \mathrm{HCl}$, and the amount of residual starch was estimated using $100 \mu \mathrm{L}$ of iodine solution $\left(0.5 \% \mathrm{I}_{2}\right.$ and $5 \% \mathrm{KI})$. The reaction volume was adjusted to $250 \mu \mathrm{L}$ by adding $15 \mu \mathrm{L}$ of distilled water, and the absorbance at $580 \mathrm{~nm}$ was measured using a spectrophotometer (Jenway, Stone, Staffordshire, UK). $\alpha$-Amylase activity was expressed as $\mu \mathrm{g}$ of starch hydrolyzed $/ \mu \mathrm{g}$ of $\mathrm{protein} / \mathrm{min}$.

\section{Assessment of $\alpha$-amylase inhibition in vitro}

The inhibitory activity of $\alpha$-amylase was determined using the method reported by Farias et al. (2007). The dry extracts was dissolved in $20 \mathrm{mM}$ sodium acetate buffer at a concentration of 10 $\mathrm{mg} / \mathrm{mL}$, and $15 \mu \mathrm{L}$ of the solution and $15 \mu \mathrm{L}$ of the insect extract were mixed and pre-incubated for $20 \mathrm{~min}$ at $37^{\circ} \mathrm{C}$. After pre-incubation, the mixture was added to $100 \mu \mathrm{L}$ of $0.2 \%$ starch solution and further incubated for $15 \mathrm{~min}$ at $37^{\circ} \mathrm{C}$. Sodium acetate buffer $(20 \mathrm{mM})$ was used as a negative control for the plant extracts. The percentage inhibition of $\alpha$-amylase was calculated based on the results of five replicates.

\section{In-gel $\alpha$-amylase assay}

Five insects fed the treated diet were homogenized in $500 \mu \mathrm{L}$ of $20 \mathrm{mM}$ sodium acetate buffer, $\mathrm{pH} 5.5$, containing $10 \mathrm{mM} \mathrm{NaCl}$ and $20 \mathrm{mM} \mathrm{CaCl}_{2}$. Fifty microliters of each sample (adjusted to contain $50 \mu \mathrm{g}$ protein) was mixed with $50 \mu \mathrm{L}$ of the sample buffer ( $0.5 \mathrm{mM}$ Tris, $10 \%$ glycerol and $0.1 \%$ bromophenol blue without mercaptoethanol), and $20 \mu \mathrm{L}$ was subjected to a slightly modified version of the polyacrylamide gel electrophoresis method of Laemmli (1970) and Campos et al. (1989). The gel consisted of $12 \%$ polyacrylamide and the run was done using Tris-glycine buffer without sodium dodecyl sulphate at $30 \mathrm{~mA}$ for $1 \mathrm{~h}$. After separation, the gel was placed in $1 \%$ Triton $\mathrm{X}-100$ solution and incubated at $4^{\circ} \mathrm{C}$ overnight. The gel was then rinsed with distilled water three times and incubated in $3 \%$ starch solution at $37^{\circ} \mathrm{C}$ for 3 h. $\alpha$-Amylase activity was stopped by first rinsing the gel in distilled water and then transferring it to a staining solution $(1.3 \%$ $\mathrm{I}_{2}$ and $\left.3 \% \mathrm{KI}\right)$. $\alpha$-Amylase activity was indicated by clear bands against a darkpurple background on the polyacrylamide gel.

\section{Determination of glucose content}

Five insects were weighed and homogenized in distilled water $(400 \mu \mathrm{L})$, boiled for $10 \mathrm{~min}$, chilled on ice and centrifuged at $15,000 \mathrm{x} g$ for $10 \mathrm{~min}$. The supernatant was mixed with 4 volumes of ice-cold methanol, incubated at $4{ }^{\circ} \mathrm{C}$ for $2 \mathrm{~h}$ and centrifuged at $15,000 \mathrm{x} \mathrm{g}$ for $10 \mathrm{~min}$. The supernatant was then transferred to a new tube and the same volume of hexane was also added. The tube was vigorously mixed and centrifuged briefly to separate the hexane and aqueous methanol layers. The lower aqueous layer was transferred to a new tube, the solvent was evaporated and the residue dissolved in $20 \mathrm{mM}$ phosphate buffer. Finally, the samples were subjected to a glucose assay using the hexokinase-glucose6-phosphate dehydrogenase method described by Bergmeyer et al. (1974). The glucose concentrations were expressed as nmol of glucose/mg of wet weight. Five replicates were performed per experiment.

\section{RNA isolation, cDNA synthesis and gene expression}

The total RNA was extracted from eggs, larvae, pupae and adults using the EZ-RNA II Total RNA Isolation Kit (Bioind, Kibbutz Beit-Haemek, Israel). The RNA samples were treated with DNaseI (Fermentas, Harrington, Ontario, Canada) followed by phenol/chloroform/isoamyl alcohol extraction and ethanol precipitation. Two hundred nanograms of each RNA sample were reverse-transcribed using oligo dT primers and reverse transcriptase (TakaraBio, Otsu, Japan) according to the manufacturer's recommendations. The primers were designed 

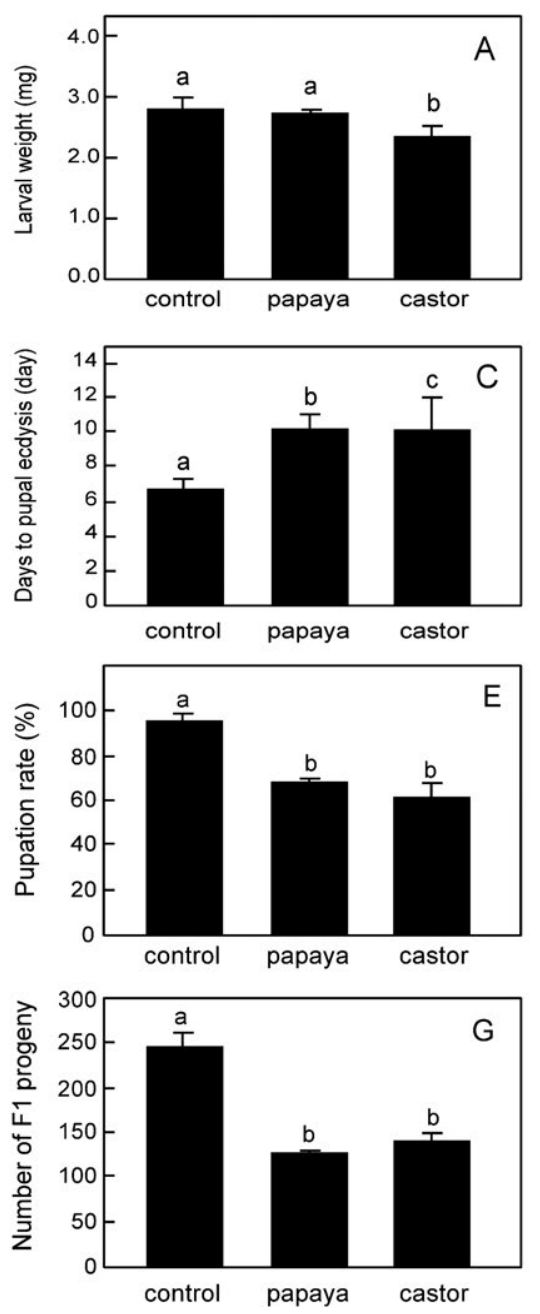

based on T. castaneum amylase genes (GenBank accession no. NM_001114376.1, XM 9703921 and XM 964141.2). The thermal cycling conditions were as follows: one cycle for 2 min at $94^{\circ} \mathrm{C} ; 35$ cycles of $15 \mathrm{~s}$ at $94^{\circ} \mathrm{C}, 30 \mathrm{~s}$ at $52^{\circ} \mathrm{C}$ and $30 \mathrm{~s}$ at $72^{\circ} \mathrm{C}$; and a final extension step at $72^{\circ} \mathrm{C}$ for $5 \mathrm{~min}$. The PCR product was subcloned, and the sequence data for the amylase gene of $T$. castaneum (TcAmy) were deposited in GenBank (accession no. JX099779). To analyze the transcription level of TcAmy, semiquantitative RT-PCR was performed using the cDNA samples $(1 \mu \mathrm{L})$ prepared from $200 \mathrm{ng}$ of total RNA sample as template and the gene-specific primer set 5'-CGAGCTTCGCCTTTGATAAC-3' and 5'-AATGGTGAAGGCGACAAATC-3' for the TcAmy gene. As an internal control, we used the T. castaneum ribosomal protein 49 gene (TcRp49), for which the primer set was designed as 5'-CAGGCACCAGTCTGACCGTTATG-3' and 5'-GCTTCGTTTTGGCATTGGAGC-3' (Minakuchi et al. 2009). PCR was performed using a Hybaid Px2 Thermal Cycler (Thermo Scientific, Waltham, MA, USA) and the following thermal cycling conditions: one cycle for 2 min at $94^{\circ} \mathrm{C} ; 28$ cycles for TcAmy or 25 cycles for TcRp 49 of $15 \mathrm{~s}$ at $94^{\circ} \mathrm{C}, 30 \mathrm{~s}$ at $55^{\circ} \mathrm{C}$ and $30 \mathrm{~s}$ at $72^{\circ} \mathrm{C}$; and a final extension step at $72^{\circ} \mathrm{C}$ for $5 \mathrm{~min}$. The PCR products were separated by electrophoresis on a $1.2 \%$ agarose gel and visualized under UV light after ethidium bromide staining. The gel images were captured digitally, and the densitometric values of the individual bands were analyzed using NIH imaging software (Scion Image). The band intensities of TcAmy in a sample were corrected to the intensities of TcRp49 and there were five replicates of all the experiments.
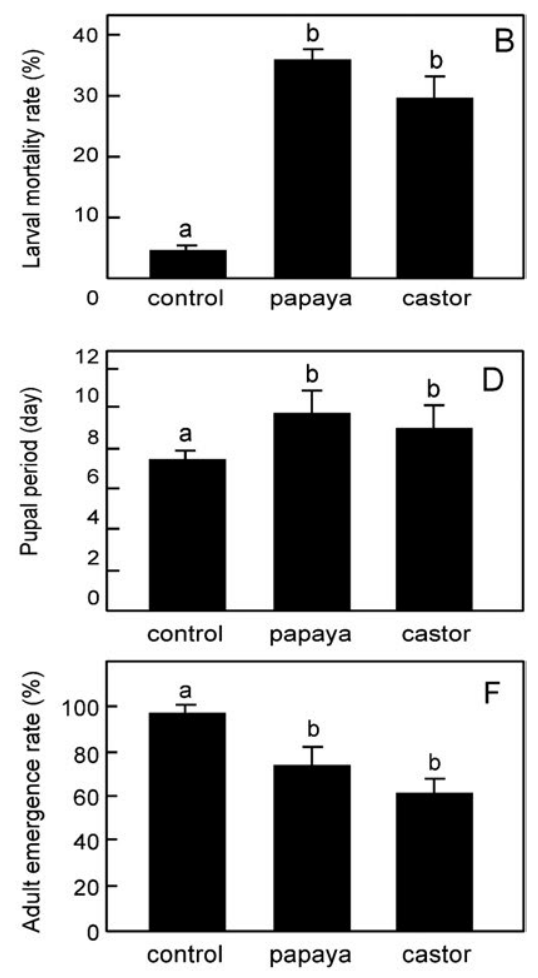

Fig. 1. Biological effects of leaf extracts of Carica papaya and Ricinus communis included in the diets fed to last-instar larvae of Tribolium castaneum. A - the effects on larval weight, recorded 5 days after treatment; $\mathrm{B}$ - percentage larval mortality; $\mathrm{C}$ - days to pupal ecdysis, calculated only for those larvae that pupated; $\mathrm{D}$ - duration of the pupal period; $\mathrm{E}$ - percentage pupation; $\mathrm{F}$ percentage adult emergence; $\mathrm{G}$ - the number of $\mathrm{F} 1$ progeny. The error bars indicate SDs and values labelled with different letters differ significantly $(P<0.05)$.

\section{Statistical analysis}

A one-wayANOVA was used to determine differences between larval weight, larval mortality, duration of larval period, duration of pupal period, percentage pupation, percentage of adult emergence, number of F1 progeny, $\alpha$-amylase activity, $\alpha$-amylase gene expression in the treatment and control. A significance level of 0.05 was used for all statistical tests.

\section{RESULTS}

\section{Effects of plant extracts on postembryonic development and $\mathrm{F} 1$ progeny production}

The average body weight of a 22-day-old larva was $2.0 \pm 0.2 \mathrm{mg}$. Five days after feeding began, the body weight of the larvae fed the control diet control was $2.9 \pm$ $0.2 \mathrm{mg}$ (Fig. 1A) and those fed the diet containing papaya extract (papaya-treated diet) was slightly less than that of the controls, but the difference was insignificant. The weight of the larvae fed the diet containing castor bean extract (castor bean-treated diet) was significantly lower than that of the other larvae $(P<0.05)$.

Despite the plant extracts' relatively weak effects on larval growth, these extracts greatly increased larval mortality. The mortality of the control larvae was $3 \%$, whereas that of the larvae fed the papaya- and castor bean-treated diets were $38 \%$ and $29 \%$, respectively (Fig. 1B). 


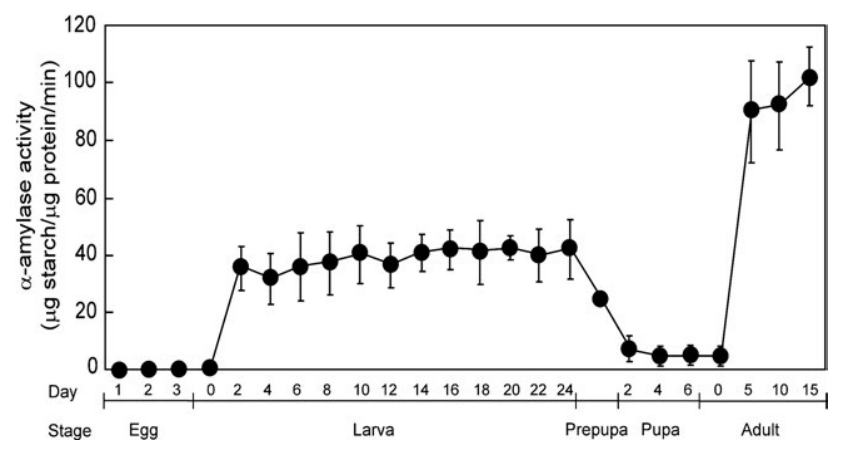

Fig. 2. Level of the $\alpha$-amylase activity recorded in the different developmental stages of Tribolium castaneum. The level of activity of $\alpha$-amylase is expressed as $\mu \mathrm{g}$ of starch hydrolyzed/ $\mu \mathrm{g}$ of protein/min. The error bars indicate SDs and values labelled with different letters differ significantly $(P<0.05)$.

The 22 day old larvae that were fed treated diets spent longer in the pupal stage. In the control group, pupal ecdysis occurred after $7.1 \pm 0.6$ days, whereas for those fed the papaya- and castor bean-treated diets it was $9.5 \pm 1.2$ and $9 \pm 2$ days, respectively, which is significantly longer than the average time spent in the pupal stage in the control group (Fig. 1C). In addition, the time spent in the pupal stage of the group fed with the papaya extract diet was significantly longer than those fed the castor bean extract diet (Fig. 1D).
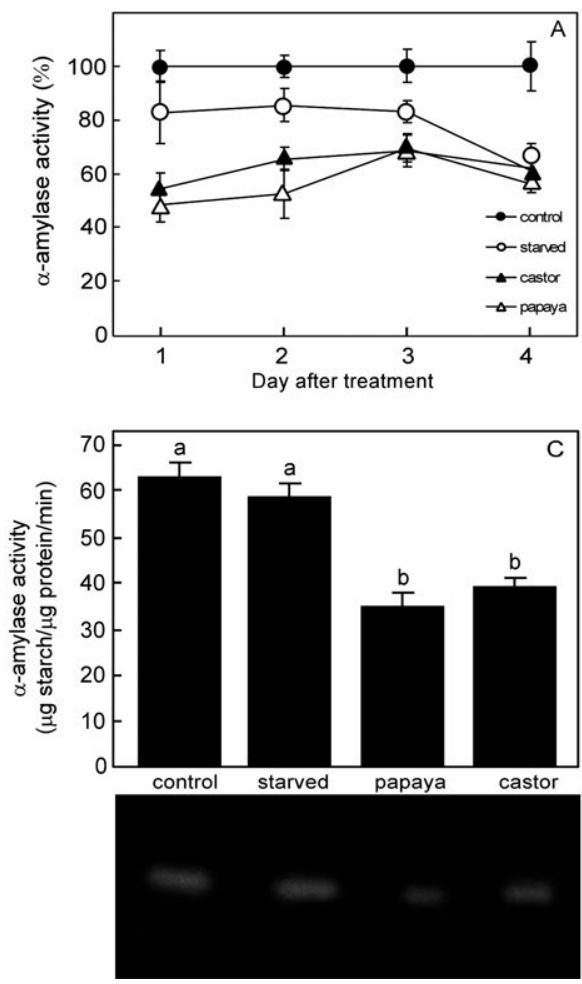

Feeding the last instar larvae on the treated diets affected the percentage that pupated and percentage of pupae that produced adults. Feeding with the papaya- and castor beantreated diets reduced the percentage that pupated to $68.8 \%$ and $62.2 \%$, respectively, of that recorded for the control (Fig. 1E). Similarly, the percentage of adult emergence from pupae produced by larvae fed the papaya- and castor bean-treated diets was $73.3 \%$ and $61.2 \%$, respectively, of that recorded for the control (Fig. 1F).

The plant extracts also reduced the fecundity of the insects. In particular, feeding a papaya- or castor bean-treated diet to adults for 2 days affected the development of their offspring. The numbers of F1 adults produced by the groups fed the papaya- and castor bean-treated diets were $127 \pm 2.8$ and $141 \pm 6.9$, respectively, both of which were significantly lower than the number produced by the control group (246 \pm 8.8$)$ (Fig. 1G).

Levels in the activity of $\alpha$-amylase and the inhibitory effects of plant extracts on this activity recorded throughout the life cycle of $T$. castaneum

Levels in $\alpha$-amylase activity were determined for all of the stages in the life cycle of T. castaneum life (Fig. 2). The activity in eggs and newly emerged, 0-day old, larvae were undetectable, but increased dramatically after the larvae began feeding when they were 2 days old and remained
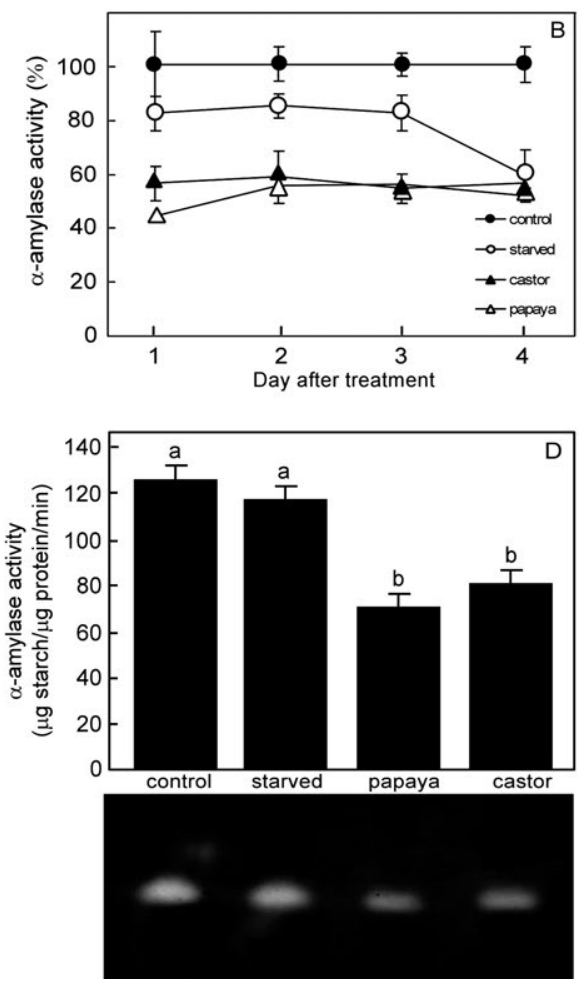

Fig. 3. Levels of $\alpha$-amylase activity recorded in Tribolium castaneum fed diets containing methanolic extracts of Carica papaya and Ricinus communis leaves. The crude samples of the enzyme were prepared from larvae (A) or adults (B) that were fed a treated diet. Two days after the treatment, the samples were collected and $\alpha$-amylase activity was determined using biochemical methods and an in-gel assay. The lower panels in (C) and (D) indicate the results of the in-gel assay of $\alpha$-amylase activity in T. castaneum fed a treated diet ( $\mathrm{C}$ for larvae, $\mathrm{D}$ for adults). The values labelled with different letters differ significantly $(P<0.05)$. In the upper panel, the samples of crude enzyme were subjected to an in vitro $\alpha$-amylase assay and the enzymatic activity expressed as described in Fig. 2. 


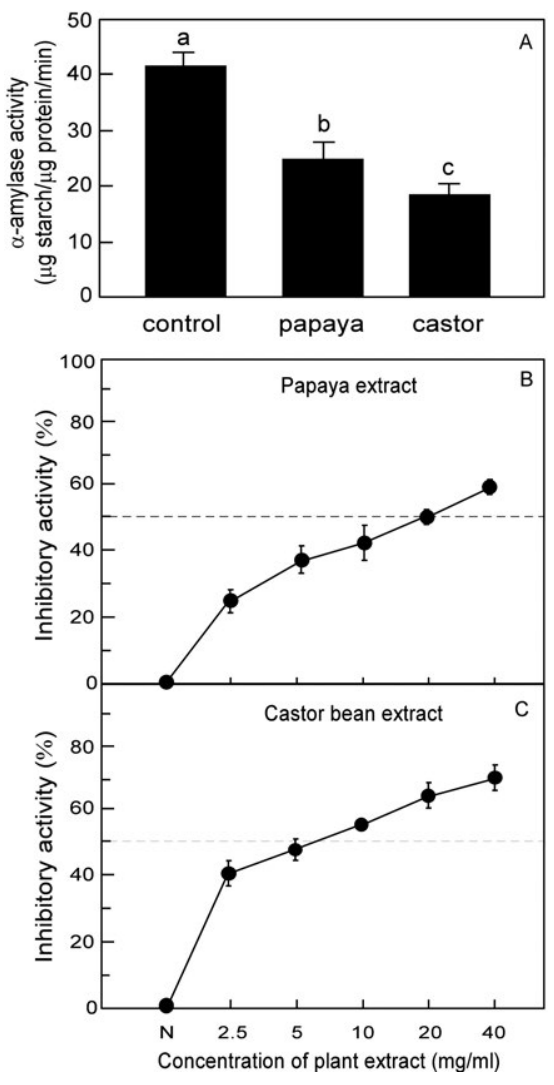

Fig. 4. In vitro inhibition of $\alpha$-amylase activity in Tribolium castaneum fed diets containing methanolic extracts of Carica papaya and Ricinus communis leaves. Inhibition of the insect's $\alpha$-amylase activity by the plant extracts was determined by incubating of $15 \mu \mathrm{L}$ of the insect extract with $15 \mu \mathrm{L}$ of the plant extracts $(10 \mathrm{mg}$ of the extracts in $1 \mathrm{~mL}$ of $20 \mathrm{mM}$ sodium acetate buffer). The enzyme activity is expressed as $\mu \mathrm{g}$ of starch hydrolyzed $/ \mu \mathrm{g}$ of protein $/ \mathrm{min}(\mathrm{A})$. The dried plant extracts of $C$. $p a-$ paya (B) and $R$. communis (C) were dissolved in $20 \mathrm{mM}$ sodium acetate buffer to give concentrations of from $2.5 \mathrm{mg} / \mathrm{mL}$ to 40 $\mathrm{mg} / \mathrm{mL}$, and their inhibition of $\alpha$-amylase was determined. In $\mathrm{N}$ only $15 \mu \mathrm{L}$ of $20 \mathrm{mM}$ sodium acetate were added to the reaction mixture. The error bars indicate SDs and values labelled with different letters in $(\mathrm{A})$ differ significantly $(P<0.05)$.

high until the prepupal stage. $\alpha$-Amylase activity then slightly decreased during the prepupal stage and remained low throughout the pupal stage. After eclosion, the activity was low in the newly emerged adults ( 0 day old) but increased markedly after feeding began. Thus, $\alpha$-amylase activity appeared to be related to feeding.

Next, we determined whether the papaya and castor bean extracts added to the diet affected $\alpha$-amylase activity. We fed the extract-treated diets to the larvae or adults and recorded $\alpha$-amylase activity for 4 days. The activity in crude extracts prepared from larvae (Fig. 3A) or adults (Fig. 3B) that were fed the treated diets was approximately half that of the controls one day after the treatment. This low activity was recorded also on the fourth day of the experiments. In starved larvae and adults, $\alpha$-amylase activity was slightly lower than in the control group and was markedly different after 4 days and similar to that recorded in insects fed with treated diets.

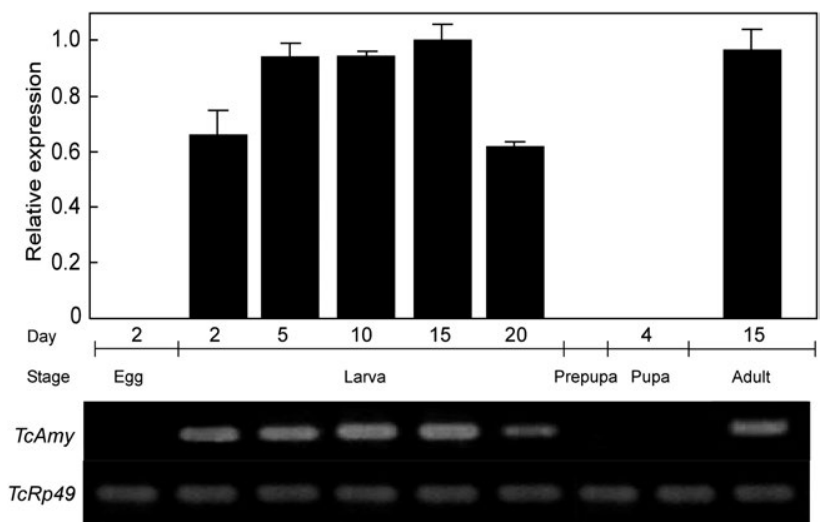

Fig. 5. Relative expression of TcAmy in the different developmental stages of Tribolium castaneum determined using RT-PCR. Samples were prepared from eggs, larvae, prepupae, pupae and adults. The PCR amplification of TcAmy, with TcRp49 used as an endogenous control (lower panel); the relative expression of TcAmy after normalization to TcRp49 expression (upper panel) and the highest normalized value of band intensities of the sample was designated as one.

Enzyme samples were extracted from larvae 2 days after the start of the treatment and subjected to an in-gel $\alpha$-amylase assay (Fig. 3C). Each zymogram produced a single band and the signal intensities of the individual bands were consistent with the $\alpha$-amylase activity measured in vitro (Fig. 3C, upper vs. lower panels). The same experiments performed on samples extracted from adults yielded similar results (Fig. 3D). The papaya and castor bean extracts strongly inhibited $\alpha$-amylase activity in vitro. Under standard assay conditions, the extract from 22-dayold larvae had an enzymatic activity of $41.4 \pm 2.6 \mu \mathrm{g}$ of $\mathrm{starch} / \mu \mathrm{g}$ of protein $/ \mathrm{min}$. The addition of papaya or castor bean extract $(10 \mathrm{mg}$ of the dry plant extracts in $1 \mathrm{~mL}$ of 20 $\mathrm{mM}$ sodium acetate buffer) to the reaction mixture reduced the enzymatic activity to $28.3 \pm 1.4$ and $18.2 \pm 3.2 \mu \mathrm{g}$ of $\mathrm{starch} / \mu \mathrm{g}$ of $\mathrm{protein} / \mathrm{min}$, respectively, equivalent to $68 \%$ and $44 \%$ of the control activity, respectively (Fig. 4A). Next, the papaya and castor bean extracts were prepared at a concentration of $40 \mathrm{mg} / \mathrm{mL}$ and serially diluted (Fig. 4B and $C$ ). Inhibitory activity ( $\%$ ) against $\alpha$-amylase increased in a concentration-dependent manner. The extract concentration for $50 \%$ inhibition $\left(\mathrm{IC}_{50}\right)$ was $20 \mathrm{mg} / \mathrm{mL}$ for the papaya extract and $6.3 \mathrm{mg} / \mathrm{mL}$ for the castor bean extract. These results indicate that papaya and castor bean leaves contain methanol-extractable factors that inhibit $\alpha$-amylase and that the papaya extract has a lower inhibitory effect than the castor bean extract.

\section{Effects of plant extracts on $\alpha$-amylase gene expression}

Semiquantitative RT-PCR was performed to determine TcAmy expression throughout the life of T. castaneum (Fig. 5). TcAmy transcripts were not detected in eggs, prepupae or pupae, whereas the expression levels were high in larvae and adults that were feeding. To examine the effects of papaya and castor bean extracts on $\alpha$-amylase at the gene level, TcAmy expression was determined after the larvae and adults were fed on a treated diet for 2 days (Fig. 6). The 

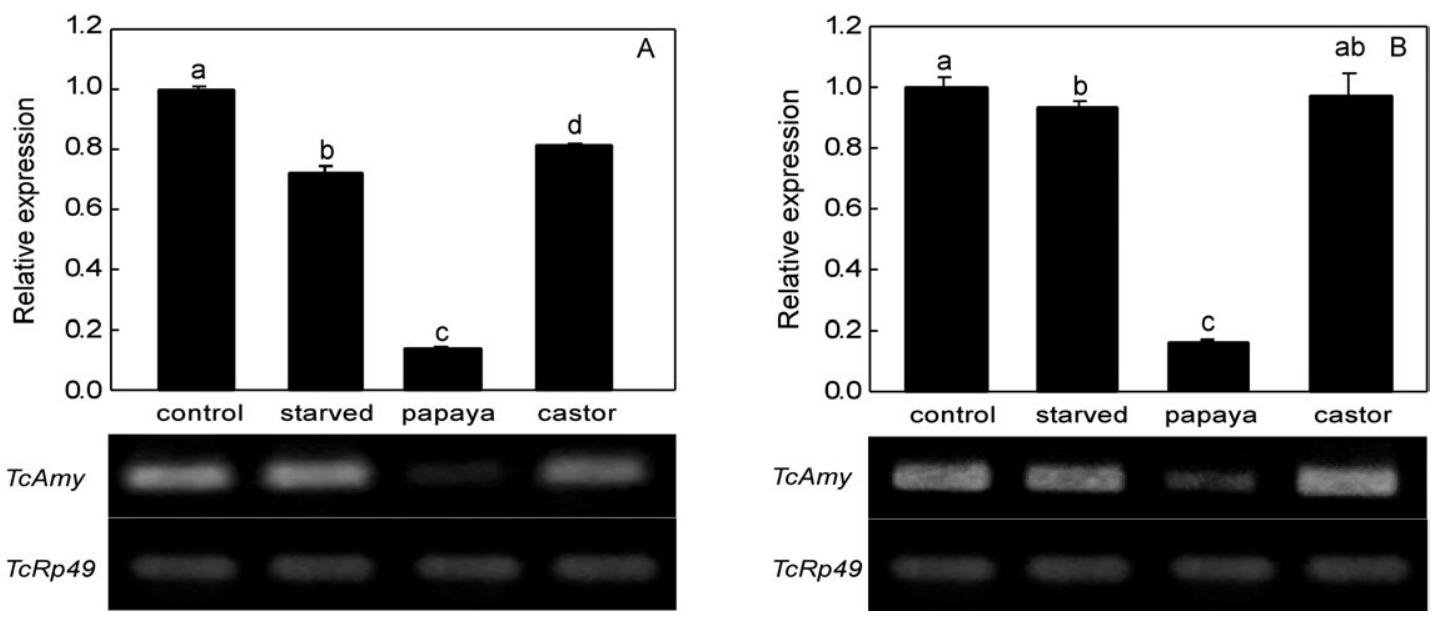

Fig. 6. Relative expression of TcAmy in Tribolium castaneum larvae (A) and adults (B) fed treated diets. Samples were collected 5 days after treatment, and TcAmy expression was determined using RT-PCR. TcRp49 was used as an endogenous control, and the expression of TcAmy was normalized to TcRp49 expression and the normalized value of band intensities of the control sample was designated as one. The values labelled with different letters differ significantly $(P<0.05)$.

TcAmy expression levels in both the larvae and the adults fed the papaya-treated diet were less than $20 \%$ of that in the controls. However, feeding them the castor bean-treated diet resulted in a slightly lowered expression in the larvae and did not affect the expression in adults.

\section{Effects of plant extracts on glucose concentration}

Because methanolic papaya and castor bean extracts inhibited $\alpha$-amylase activity, we determined whether these extracts also induced a decrease in glucose content in $T$. castaneum. More specifically, we measured the glucose concentration in the larvae and adults that were fed on a treated diet for 2 days (Fig. 7). The glucose concentrations in the larvae and adults fed the treated diets were approximately $50 \%$ of those in the control larvae. In contrast, in starved larvae and adults, the glucose concentrations were $21.8 \%$ and $25.4 \%$, respectively, of that in the controls.

\section{DISCUSSION}

In the present study, we found that extracts of papaya and castor bean leaves inhibit growth and postembryonic development in T. castaneum. A plant species may express substances with a wide range of activities that may jointly or independently exert a variety of deterrent effects (Franco et al., 2002). Here, we show that methanolic extracts of papaya and castor bean leaves have several inhibitory effects on $T$. castaneum, including prolongation of the duration of the larval and pupal periods and reduction in the percentage that pupate and emerge as adults and F1 progeny production. However, the intensity of the inhibitory effects differed depending on the developmental stages and nature of the plant extract. The papaya extract did not reduce larval weight, whereas the castor bean extract had a weak affect in decreasing larval weight, but larval mortality was greatly increased by both extracts. These different effects suggest the presence of several inhibitory factors in plants, although the components mediating the individual deterrent effects remain to be identified. An aqueous extract of castor bean leaves affects oviposition activity in the banana weevil, Cosmopolites sordidus (Tinzara et al., 2006). Other reports demonstrate that extracts of castor bean leaves and seeds have potential insecticidal, ovicidal
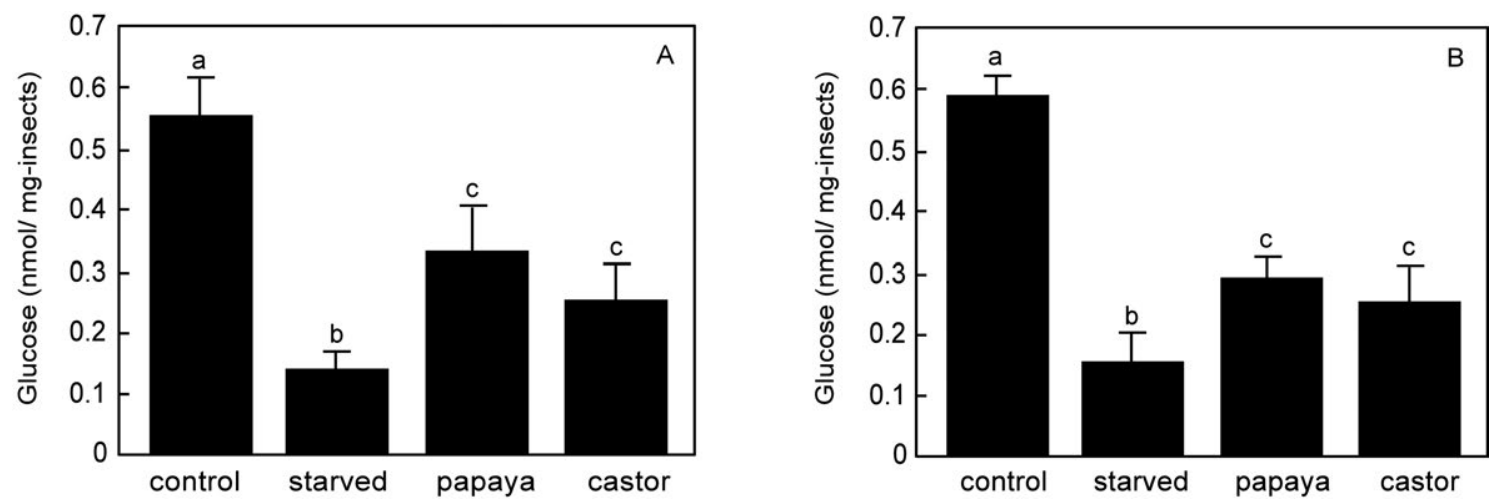

Fig. 7. Glucose concentration in Tribolium castaneum larvae (A) and adults (B) fed diets containing methanolic extracts of Carica papaya or Ricinus communis leaves. Samples were collected 2 days after treatment. The glucose content is given in nmol of glucose/ $\mathrm{mg}$ wet weight. The values labelled with different letters differ significantly $(P<0.05)$. 
and oviposition-deterring activity against Callosobruchus chinensis and that it is quercitin, the principal flavonoid in this extract, which has these insecticidal properties (Upsani et al., 2003; Singh \& Chauhan, 2009). Similarly, 50\% of the larvae of cowpea weevil Callosobruchus maculatus fed extracts of papaya seeds die and the longevity and fecundity of the adults is reduced (Farrias et al., 2007). This insecticidal effect is attributed to the latex present in papaya leaves, which contains cysteine protease, which is strongly toxic, inhibits growth and causes the larvae of lepidoptera, including Samia cynthia ricini, Mamestra brassicae and Spodoptera litura, to lose weight (Konno et al., 2007). In the present study, methanol extracts of papaya and castor leaves fed to larvae resulted in a prolongation of the length of larval and pupal periods. According to Rodriguez-Hernandez \& Vendramim (1996), extension of the larval stage is due to inhibition of growth and extension of the pupal stage to inhibition of development, which indicates that papaya and castor bean leaves extracts affect both growth and development in T. castaneum.

Developmental stage-specific changes in enzymatic activity are reported as occurring in the confused flour beetle, Tribolium confusum (Bandani \& Balvasi, 2006), larger grain borer, Prostepanus truncatus (Mediola-Olaya et al., 2000), bark beetle, Ips typographus (Viktorinova et al., 2011) and cotton bollworm, Helicoverpa armigera (Kotkar et al., 2009). In these species, high activity during the larval and adult stages and low activity during the prepupal period are commonly recorded. Accordingly, the change in $\alpha$-amylase activity in $T$. castaneum appears to be well correlated with feeding, as this activity occurs in larvae and adults but not in eggs and pupae. In larvae and adults, however, the activity was not detected on the first day of these developmental stages. Because wheat flour is a major source of starch for $T$. castaneum, this species may rely on $\alpha$-amylase for digestion, resulting in the high $\alpha$-amylase activity recorded in feeding insects.

The reduction in $\alpha$-amylase activity by plant extracts may be caused by plant defence compounds, including inhibitors, which act on insect enzymes such as hydrolase, $\alpha$-amylase and proteinase (Franco et al., 2002) and other digestive enzymes (Jing et al., 2005; Senthil, 2006; Tatun et al., 2014). The seeds of C. papaya contain a novel inhibitor of the $\alpha$-amylase of cowpea weevil, $C$. maculatus, which does not inhibit the activity of mammalian $\alpha$-amylase (Farias et al., 2007). The $\alpha$-amylase inhibitors extracted from papaya seeds increased larval mortality by up to $50 \%$ and decreased insect fecundity. The seed of $R$. communis contains $2 \mathrm{~S}$ albumins, major allergens, which inhibit in a dose dependent manner the activity of $\alpha$-amylases in the guts of larvae of C. maculatus, Zabrotes subfasciatus and Tenebrio molitor and human salivary $\alpha$-amylases (Do Nascimento et al., 2011). Bioassays demonstrate that $2 \mathrm{~S}$ albumin incorporated into the diet of $C$. maculatus reduced larval growth by $20 \%$. In addition, the reduction of $\alpha$-amylase activity may be due to the cytotoxic effects of plant extracts on the epithelial cells of the midgut, which synthesize $\alpha$-amylase (Cristofoletti et al., 2001). The cytotoxic effect of the ex- tract of Peganum harmala results in the disorganization of the midgut epithelial cells of the larvae of $T$. castaneum (Jbilou et al., 2008) However, a cytological study of the effects of extracts from papaya and castor bean leaves on the midgut of $T$. castaneum remains to be done. Because $\alpha$-amylase converts starch into maltose, which is then hydrolyzed into glucose by $\alpha$-glucosidase (Terra \& Ferreira, 2005), the decrease in glucose concentration recorded in $T$. castaneum fed the diet treated with papaya or castor bean extract may be due to the inhibition of $\alpha$-amylase activity resulting in the lack of carbohydrate source, as those extracts inhibited insect development.

In T. castaneum, TcAmy gene expression was high during the larval and adult stages but was not detected in the egg, prepupal and pupal stages. Similar stage-specific expression is recorded in I. typographus (Viktorinova et al., 2011) and H. armigera (Kotkar et al., 2012), indicating that the expression of the amylase gene may be connected to feeding. In $T$. castaneum, the developmental change in $\alpha$-amylase activity may be primarily caused by stage-specific TmAmy expression. In H. armigera, dietary sugar is involved in the regulation of the expression of the $\alpha$-amylase gene (HaAmy). More specifically, the expression of HaAmy is suppressed by the high sucrose content of its host plants (Kotkar et al., 2012). Here we report for the first time that methanol extract of $C$. papaya affected the expression of the TcAmy gene. However there are no other reports of plant extracts suppressing insect amylase gene expression and further studies are needed to determine how this plant extract affects TcAmy gene expression in $T$. castaneum

The results presented here demonstrate that the two extracts contain two different classes of inhibitors, which equally inhibit development and $\alpha$-amylase activity in $T$. castaneum. Castor bean leaf extract contains only a single class of inhibitors that block $\alpha$-amylase, whereas papaya extract contains two classes of inhibitor, with one blocking $\alpha$-amylase activity and a second blocking TcAmy expression. Used together these plant extracts could reduce the damage caused by this insect pest.

ACKNOWLEDGMENTS. This study was supported by the Thailand Research Fund (MRG5380199) awarded to NT.

\section{REFERENCES}

BAKER J.E. 1991: Purification and partial characterization of $\alpha$-amylase allozymes from the lesser grain borer, Rhyzopertha dominica. - Insect Biochem. 21: 303-311.

BANDANI A.R. \& BALVASI A. 2006: Comparison of alpha-amylase activity in larval stages of flour beetles, Tribolium confusum (Coleoptera: Tenebionidae). - Commun. Agri. Appl. Biol. Sci. 71: $537-541$.

Bergmeyer H.U., Bernt E., Schmidt F. \& Stork H. 1974: DGlucose determination with hexokinase and glucose-6-phosphate dehydrogenase. In: Bergmeyer, H.U. (Ed.), Methods of Enzymatic Analysis, vol. 3. Academic Press, New York, pp 1196-1201.

Campos F.A.P., Xavier-Filfo J., Silva C.P. \& Ary M.B. 1989: Resolution and partial characterization of proteinase and amyl- 
ase from midgut of larvae of the bruchid beetle Callosobruchus maculatus (F). - Comp. Biochem. Physiol. 92: 51-57.

Cristofoletti P.T., Ribeiro A.F. \& Terra W.R. 2001: Apocrine secretion of amylase and exocytosis of trypsin along the midgut of Tenebrio molitor larvae. - J. Insect Physiol. 47: 143-155.

Do Nascimento V.V., Castro H.C., Abreu P.A., Oliveira A.E., Fernandez J.H., ARaúJo Jda S. \& Machado O.L. 2011: In silico structural characteristics and $\alpha$-amylase inhibitory properties of Ric $\mathrm{c} 1$ and Ric c 3, allergenic 2S albumins from Ricinus communis seeds. - J. Agri. Food Chem. 59: 4814-4821.

Farias L.R., Costa F.T., Souza L.A., Pelegrini P.B., Grossi-DeSÁ M.F. \& Neto S.M. 2007: Isolation of a novel Carica papaya $\alpha$-amylase inhibitor with deleterious activity toward Callosobruchus maculatus. - Pestic. Biochem. Phys. 87: 255-260.

Feng G., Chen M., Kramer K.J. \& Reeck G.R. 1996: $\alpha$-amylase inhibitors from rice: fractionation and selectivity toward insect, mammalian and bacterial $\alpha$-amylases. - Cereal Chem. 68: $516-521$.

Franco O.L., Melo F.R., Mendes P.A., Paes N.S., Yokoyama M., Coutinho M.V., Bloch C.JR. \& Grossi-DE-SÁ M.F. 2005: Characterization of two Acanthoscelides obtectus alpha-amylases and their inactivation by wheat inhibitors. - J. Agric. Food Chem. 53: 1585-1590.

Franco O.L., Rigden D.J., Melo F.R. \& Grossi-De-Sa M.F. 2002: Plant $\alpha$-amylase inhibitors and their interaction with insect $\alpha$-amylase. Structure, function and potential for crop protection. - Eur. J. Biochem. 269: 397-412.

Jbilou R., Amri H., Bouayad N., Ghailani N., EnNabili A. \& Sayah F. 2008: Insecticidal effects of extracts of seven plant species on larval development, $\alpha$-amylase activity and offspring production of Tribolium castaneum (Herbst) (Insecta: Coleoptera: Tenebrionidae). — Bioresour. Technol. 99: 959-964.

Jing L., Fang Y., Ying X., Wenxing H., Meng X., Syed M., Syed N. \&FANG C. 2005: Toxic impact of ingested Jatropherol-1 on selected enzymatic activities and the ultrastructure of midgut cells in silkworm Bombyx mori L. - J. Appl. Entomol. 129: 98-104.

Konno K., Hirayama C., Nakamura M., Tateishi K., Tamura Y., HATtoRi M. \& KohNo K. 2007: Papain protects papaya trees from herbivorous insects: role of cysteine proteases in latex. Plant J. 37: 370-378.

KotKar H.M., Bhide J.A., Gupta S.V. \& Giri P.A. 2012: Amylase gene expression patterns in Helicoverpa armigera upon feeding on a range of host plants. - Gene. 501: 1-7.

Koul O. \& Dhawiwal G.S. 2001: Phytochemical Biopesticides. Harwood academic publisher, Australia.

LaEMmLi U.K. 1970: Cleavage of structural proteins during the assembly of the head of the bacteriophage T4. - Nature. 227: 680-685.

Minakuchi C., Namiki T. \& Shinoda T. 2009: Krüppel homolog 1 , an early juvenile hormone-response gene downstream of
Methoprene-tolerant, mediates its anti-metamorphic action in the red flour beetle Tribolium castaneum. - Dev. Biol. 325: 341-350.

Rekha M.R., Sasikiran K. \& Padmaja G. 2004: Inhibitor potential of protease and $\alpha$-amylase inhibitors of sweet potato and taro on the digestive enzymes of root crop storage pests. $-J$. Stored Prod. Res. 40: 461-470.

Rodríguez-Hernández C. \& VendRAmim D.J. 1996: Toxicidad de extractos de Meliaceae en Spodoptera frugiperda (Lepidoptera: Noctuidae). - Manejo Integrado de Plagas 42: 14-22.

SeNTHIL N.S. 2006: Effects of Melia azedarach on nutritional physiology and enzyme activities of rice leaffolder Cnaphalocrocis medinalis (Guenee) (Lepidoptera: Pyralidae). — Pectic. Biochem. Physiol. 84: 98-108.

Singh P.P. \& Chauhan A.S.M.S. 2009: Activity guided isolation of antioxidants from the leaves of Ricinus communis L. Food Chem. 114: 1069-1072.

Strobl S., Maskos K., Weigand G., Huber R., Gomis Ruth F.X. \& Glockshuber R. 1998: A novel strategy for inhibition of alpha-amylases: yellow mealworm alpha-amylase in complex with Ragi bifunctional inhibitor at $2.5^{\circ} \mathrm{A}$ resolution. - Structure. 6: 911-921.

Tatun N., Vajarasathira B., Tunguttwitayakul J. \& Sakurai S. 2014: Inhibitory effects of plant latex on trehalase activity and trehalase gene expression in the red flour beetle, Tribolium castaneum (Coleoptera: Tenebrionidae). Eur. J. Entomol. 111: $11-18$.

Terra W.R. \& Ferreira C. 2005: Biochemistry of digestion. In: Gilbert, LI, Iatrou K, Gill SS (eds), Comprehensive Molecular Insect Science. Biochemistry Molecular Biology, Vol. 4. Elsevier, Amsterdam, pp 171-224.

Tinzara W., Tushemereirwe W., Nankinga C.K., Gold C.S. \& KashaIJA I. 2006: The potential of using botanical insecticides for the control of the banana weevil, Cosmopolites sordidus (Coleoptera:Curculionidae). - Afr. J. Biotechnol. 5: 19941998.

Viktorinova I., Kucerova L., Bohmova M., Henry I., Jindra M., Dolezal P., Zurovcova M. \& Zurovec M. 2011: Characterization of two closely related $\alpha$-amylase paralogs in the bark beetle, Ips typographus (L.). - Arch. Insect Biochem. Physiol. 77: 179-198.

Upasani S.M., KotKar H.M., MendKi P.S. \& Maheshwari V.L. 2003: Partial characterization and insecticidal properties of Ricinus communis L. foliage. - Pest Manag. Sci. 59: 13491354.

ZettLeR L.J. 1991: Pesticide resistance in Tribolium castaneum and Tribolium confusum (Coleoptera, Tenebrionidae) from flour mills in the United States. - J. Econ. Entomol. 84: 763767.

Received September 2, 2013; revised and accepted November 15, 2013 Prepublished online February 25, 2014 